\title{
WATER TREATMENT IN THE EBR-II STEAM SYSTEM
}

Compiled by Matthew A. Klein and Howard Hurst

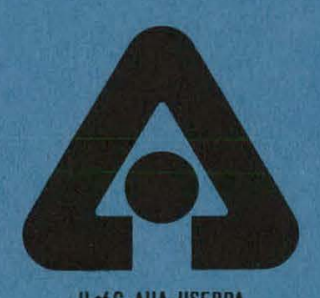

U Of C-AUA-USERDA

\section{EBR-II PROJECT \\ ARGONNE NATIONAL LABORATORY \\ Argonne, Illinois - Idaho Falls, Idaho}

January 1975

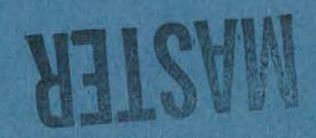




\section{DISCLAIMER}

This report was prepared as an account of work sponsored by an agency of the United States Government. Neither the United States Government nor any agency Thereof, nor any of their employees, makes any warranty, express or implied, or assumes any legal liability or responsibility for the accuracy, completeness, or usefulness of any information, apparatus, product, or process disclosed, or represents that its use would not infringe privately owned rights. Reference herein to any specific commercial product, process, or service by trade name, trademark, manufacturer, or otherwise does not necessarily constitute or imply its endorsement, recommendation, or favoring by the United States Government or any agency thereof. The views and opinions of authors expressed herein do not necessarily state or reflect those of the United States Government or any agency thereof. 


\section{DISCLAIMER}

Portions of this document may be illegible in electronic image products. Images are produced from the best available original document. 
The facilities of Argonne National Laboratory are owned by the United States Government. Under the terms of a contract (W-31-109-Eng-38) between the U. S. Energy Research and Development Administration, Argonne Universities Association and The University of Chicago, the University employs the staff and operates the Laboratory in accordance with policies and programs formulated, approved and reviewed by the Association.

\section{MEMBERS OF ARGONNE UNIVERSITIES ASSOCIATION}

The University of Arizona

Carnegie-Mellon University

Case Western Reserve University

The University of Chicago

University of Cincinnati

Illinois Institute of Technology

University of Illinois

Indiana University

Iowa State University

The University of Iowa
Kansas State University The University of Kansas Loyola University Marquette University Michigan State University The University of Michigan University of Minnesota University of Missouri Northwestern University University of Notre Dame
The Ohio State University Ohio University

The Pennsylvania State University Purdue University

Saint Louis University Southern Illinois Univorsity The University of Texas at Austin 1. Washington University Wayne State University The University of Wisconsin

This report was prepared as an account of work sponsored by the United States Government. Neither the United States nor the United States Energy Research and Development Administration, nor any of their employees, nor any of their contractors, subcontractors, or their employees, makes any warranty, express or implied, or assumes any legal liability or responsibility for the accuracy, complcteness or usefulness of any information, apparatus, product or process disclosed, or represents that its use would not infringe privately-owned rights. Mention of commercial products, their manufacturers, or their suppliers in this publication does not imply or connote approval or disapproval of the product by Argonne National Laboratory or the U. S. Energy Research and Development Administration. 
THIS PAGE

\section{WAS INTENTIONALLY LEFT BLANK}


TABLE OF CONTENTS

$\underline{\text { Page }}$

ABSTRACT . . . . . . . . . . . . . . . . . . 9

I. INTRODUCTION . . . . . . . . . . . . . . . . . 9 9

II. DESCRIPTION OF STEAM SYSTEM . . . . . . . . . . . . 10

A. Steam Generation and Description . . . . . . . . 10

B. Water Systems ............... 13

1. Condensate . . . . . . . . . . . . . 13

2. Feedwater ................ 13

3. Blowdown .................. . . 17

4. Makeup Water . . . . . . . . . . . . . 17

5. Cooling Water ............... 17

III. TREATMENT OF MADEUP WATER AND BLOWDOWN . . . . . . . . . 17

A. Makeup Water . . . . . . . . . . . . . 19

1. Preliminary Demineralizers . . . . . . . . . 19

2. Secondary Demineralizers . . . . . . . . . 19

3. Startup and Operation ... . . . . . . . . 21

4. Regeneration of Columns . . . . . . . . . . 21

5. Ëffluent-water Quality ............ 22

B. Blowdown . . . . . . . . . . . . . . 24

1. Treatment System . . . . . . . . . . . . 24

2. Operation ................ . . 24

IV. TREATMENT OF BOILER FEEDWATER . . . . . . . . . . . . . 25

A. Treatment System . . . . . . . . . . . . . 25

1. Hydrazine Injection . . . . . . . . . . 26

2. Morpholine Injection . . . . . . . . . . 27 
TABLE OF CONTENTS (contd)

$\underline{\text { Page }}$

B. Procedures During Plant Operation . . . . . . . . 27

1. Startup . . . . . . . . . . . . . . 27

a. Filling Condensate System with Treated Water ... 27

b. Filling the Feedwater System . . . . . . . 27

c. Filling the Feedwater and Blowdown-system Yard Piping . . . . . . . . . . . . . . 28

d. Heating Heater No. 2 and the Yard Piping for the Feedwater and Dlowdown Systems . . . . . . . 28

e. Filling the Steam Generator with Treated Water : 28

f. Heatup of Steam System to $350^{\circ} \mathrm{F}$. . . . . . 28

g. Heatup from $350^{\circ} \mathrm{F}$ to Standby Condition at $580^{\circ} \mathrm{F}$. 28

2. Normal Power Operation . . . . . . . . . . 28

a. $\mathrm{pH}$ and Conductivity Monitoring . . . . . . 28

b. Hydrazine and Oxygen Monitoring . . . . . . . . 29

3. Plant Shutdown. . . . . . . . . . . . . . . 29

4. Plant standby . . . . . . . . . . . . . . . 29

5. Plant Cooldown .. . . . . . . . . . . . . . . 29

6. Inleakage of Condenser Cooling Water . . . . . 30

a. Specifications for Uperation with Leakage of
Condenser Cooling Water............ 30

(1) Water Conditions (allowable range). . . . 30

v. SARTLING ARD MONITORING SYSTEM . . . . . . . . . . . . . . 31

A. Components and Operation . . . . . . . . . . . 31

B. Schedules . . . . . . . . . . . . . . . . 34

1. Condensate (Sampling Station S-1)......... . 34

a. $\mathrm{pH}$ (grab sample). . . . . . . . . . . 34 
TABLE OF CONTENTS (contd)

Page

2. Deaerator Effluent (Sampling Station S-2). . . . . 34

3. Blowdown (Sampling Station $\$$-4). . . . . . . . . 34

4. Boiler Feedwater (Sampling Station S-5).. . . . . 34

5. Steam (Sampling Station S-6) ........... 35

6. Makeup Feedwater (Polishing Demineralizer Effluent). . 35

C. Analytical Data . . . . . . . . . . . . . 35

VI. HISTORY OF WATER TREATMENT FOR EBR-II . . . . . . . . . . 35

A. Installation, Preconditioning, and Chemical Cleaning . ... 35

B. Prepower, Hot Operation; and Wet Criticality . . . . . 36

C. Approach to Power Operation . . . . . . . . . . 36

D. Water Leak at Tube-to-Tubesheet Weld . . . . . . . . . 37

E. Leak in Main-condenser Tube . . . . . . . . . . . 37

F. Inspections of Evaporator Steam Drum . . . . . . . . . 37

1. Methods . . . . . . . . . . . . . 38

2. Results ................... 38

VII. CONCLUSION . . . . . . . . . . . . . . . . . 39

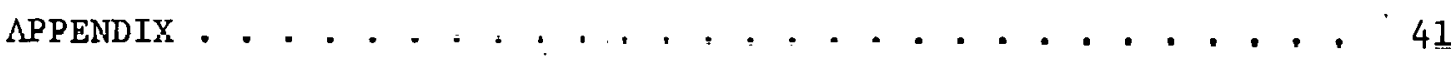

REFERENCE . . . . . . . . . . . . . . . . . . . . . 48 


\section{LIST OF FIGURES}

No.

Title

$\underline{\text { Page }}$

1.

Simplified Diagram of Flow of Water in EBR-II Steam System

2 .

Steam Generation and Distribution . . . . . . . . . 12

3.

Condensate System . . . . . . . . . . . . 15

4.

Feedwater System . . . . . . . . . . . . . 16

5.

Bluwdown System . . . . . . . . . . . . . . 18

6.

Typical Water-sampling Station . . . . . . . . . 


\section{LIST OF TABLES}

No.

Title

Page

I. Normal Water Conditions in EBR-II Streams . . . . . . .

II. Analysis of EBR-II Well Water..............

III. Specifications for Water from the Makeup System . . . .

IV. Analyses of Deposits in Evaporator Tubesheets and Tubes.

V. Hydrazine and Dissolved Oxygen in Feedwater and Heater No. 2 for Run 40 . . . . . . . . . . . . . .

VI. Hydrazine and Dissolved Oxygen in Feedwater and Heater No. 2 for Run 44 ..................

VII. Spectrophometric Analysis of Steam-Feedwater System for Run 40 (ppm) . . . . . . . . . . . . . .

VIII. Spectrophotometric Analysis of Steam-Feedwater System for Run 42 (ppm) . . . . . . . . . . . . . .

IX. $\mathrm{pH}$ of Steam-Feedwater System/for Run 40 ........

X. $\quad \mathrm{pH}$ of Steam-Feedwater System for Run 44 ........ 


\section{THIS PAGE \\ WAS INTENTIONALLY \\ LEFT BLANK}


WATER TREATMENT IN THE EBR-II STEAM SYSTEM

Compiled by

Matthew A. Klein and Howard Hurst

ABSTRACT

Boiler-water treatment in the EBR-II steam system consists of demineralizing makeup water and using hydrazine to remove traces of oxygen and morpholine to adjust $\mathrm{pH}$ to 8.8-9.2. This treatment is called a "zero-solids" method, because the chemical agents and reaction products are either volatile or form water and do not contribute solids to the boiler water. A continuous blowdown is cooled, filtered, and deionized to remove impurities and maintain high purity of the water. If a cooling-water leak occurs, phosphate is added to control scaling, and the "zero-solids" treatment is suspended until the leak is repaired. Water streams are sampled at six points to control water purity. Examination of the steam.drum and an evaporator show the metal surfaces to be in excellent condition with minimal corrosion.

The EBR-II steam-generating plant has accuimulated over 85,000 hours of in-servlce operation and has operated successfully for over ten years with. the "zerosolids" treatment.

\section{INTRODUCTION}

The Experimental Breeder Reactor No. 2 (EBR-II) is a heterogeneous, unmoderated sodium-cooled reactor with a design full-power rating of 62.5 MWt and 20.0 MWt electrical. Wet-critical operation was achieved on November 11, 1967. The approach to power was begun in July 1964. Ae of the end of 1974; the cumulative amount of thermal energy that had been produced by EBR-II 
exceeded 2 billion $\mathrm{kWh}$.

This report presents the operating experience with the water-treatment system from more than ten years of successful operation of the EBR-II steamgenerating system.

The type of water treatment employed at EBR-II is not unusual nor is its use by the industry, but is unique in that it has been successfully used over ten years with a liquid-metal-cooled fast breeder reactor with a minimum of problems and no serious incidents.

For a general survey of experience with the steam system, see ref. 1 .

\section{DESCRTP'TUN OF. STEAM EYSTEM}

The steam system at EBR-II removes heat from the secondary sodium system. Heat produced in the primary-sodium system is removed by the secondary-sodium system in the intermediate heat exchanger (IHX) and transferred to the steam system via the evaporators and superheaters of the steam generator. The principal requirement of the steam system is to provide a relatively constant evaporator saturation temperature of about $580^{\circ} \mathrm{F}$ for all power levels of reactor operation, with or without the turbine-generator in operation.

The steam generator uses the heat delivered by the secondary sodium to produce superheated steam at $820^{\circ} \mathrm{F}, 1250 \mathrm{psig}$, and delivers $248,100,1 \mathrm{~b} / \mathrm{hr}$ (whcn the reaclur 1s operating at $62.5 \mathrm{MWt}$ ) to a conventionally designed turbine generatior to produce a maximum of 20 MWe.

The steam system consists of six subsystems: (a) Steam generation and distribution; (b) Condensate; (c) Feedwater; (d) Blowdown; (e) Makeup water; and (f) Cooling water.

Figuie 1 is a simplitied dfagram of the flow of water in the steam system.

\section{A. Steam Generation and Diatrihutiou}

This system (Fig. 2) consists of a steam generator, which extracts the heat from the secondary sodium and produces superheated steam at $820^{\circ} \mathrm{F}$; a turbine, which uses the steam to power a generator to produce electrical power; and a steam-bypass system, which dissipates excess steam directly to the condenser. The steam generator consists of a steam drum with moisture-separating components; eight she11-and-tube recirculating evaporators; and two shell-and- 


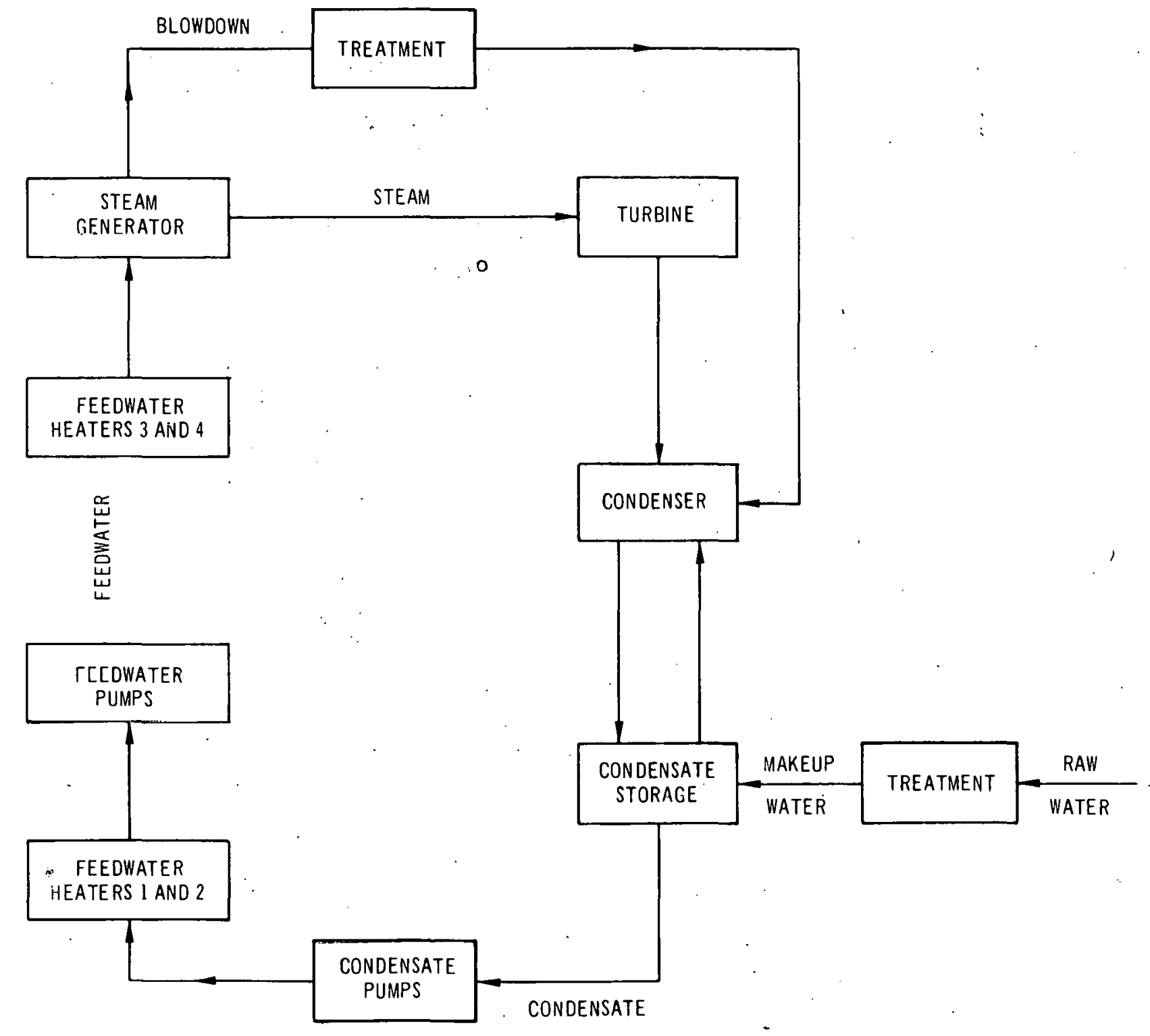

Fig. 1. Simplified Diagram of Flow of Water in EBR-II Sream System 


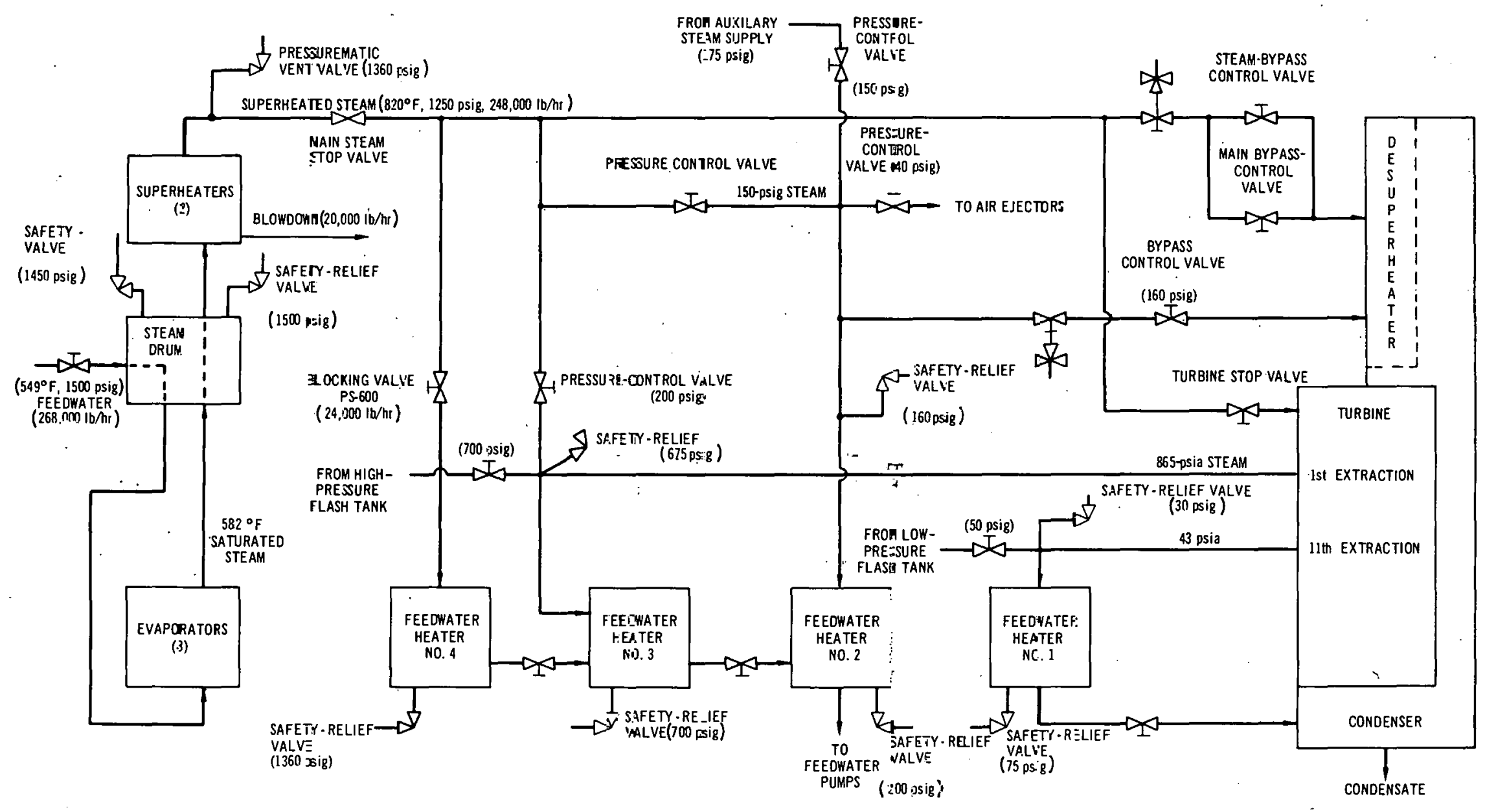

Fig. 2. Steam Generation and Distribution 
tube once-through superheaters.

\section{B. Water. Systems}

Because the EBR-II steam system is closed, makeup water is added only to replace losses from leaks. The streams treated are makeup water, feedwater, and blowdown. These and other sțreams are sampled and analyzed at all stages of reactor operation and during shutdowns. Normal water conditions are given in Table $I$.

\section{Condensate}

The condensate system (Fig. 3) consists of a main surface condenser that condenses the steam; a desuperheater to temper bypass steam; an air ejector that removes air and other noncondensable gases from the condenser; condensate pumps that circulate the condensate; and a condensate-storage tank. The main surface condenser is a tube-and-shell exchanger connected to the exhaust outlet of the turbine. Cooling water flows in the tube side and removes heat from the turbine-exhaust steam or bypass steam circulating in the shell. The desuperheater tempers the bypass steam before it enters the condenser she11. The condensate collects in the condenser hotwell and is used as a continuing supply of feedwater. The condensate-storage tank receives demineralized makeup water from the makeup-water system and excess water from the deaerator-feedwater heater No. 2. It feeds the water to the condenser hotwell when the water level is low in the well. Two centrifugal pumps, one operating and one on standby, pump condensate from the condenser hotwell through the air ejectors and blowdown cooler to the feedwater heaters.

\section{Feedwater}

The feedwater system (Fig. 4) consists of four feedwater heaters that incrementally heat condensate from $109^{\circ}$ to $550^{\circ} \mathrm{F}$ for charging to the steam generator, and three feedwater pumps to circulate the water. Feedwater heaters Nos. 1, 3, and 4 are she11-and-tube type heat exchangers; feedwater heater No. 2 is a direct-contact tray-type, vertical deaerating heater with an integral storage tank. Only one feedwater pump is used at a time. The startup pump, 
TABLE I. Normal Water Conditions in EBR-II Streams

\begin{tabular}{|c|c|c|c|c|c|}
\hline Content, ppm & Condensate & $\begin{array}{c}\text { Blowdown- } \\
\text { demineralizer } \\
\text { Effluent }\end{array}$ & Blowdown & Feedwater & Steam \\
\hline $\mathrm{pH}$, average & 8.8 & 8.0 & 8.8 & 8.9 & 8.9 \\
\hline $\mathrm{O}_{2}, \mathrm{ppb}$ & - & -- & - & $<5$ & -- \\
\hline Hydrazine & -- & -- & -- & $0.01-0.03$ & -- \\
\hline $\mathrm{NH}_{3}$ & $0.3-0.8$ & nil & $0.3-0.8$ & $0.3-0.8$ & $0.3-0.8$ \\
\hline $\mathrm{CH}$ & $\therefore 0.01$ & 0.01 & $<0.01$ & $<0.01$ & $<0.01$ \\
\hline $\mathrm{Cu}$ & $<0.05$ & - & $<0.05$ & $<0.05$ & $\because-$ \\
\hline $\mathrm{Fe}$ & $<0.01$ & -- & $<0.01$ & $<0.01$ & -- \\
\hline Morpholine & $2-8$ & nil & $2-8$ & $2-8$ & $2-8$ \\
\hline $\mathrm{SiO}_{2}$ & $<0.05$ & - & $<0.05$ & $<0.05$ & $<0.05$ \\
\hline Total Hardness & $<0.05$ & $<0.05$ & $\therefore 0.05$ & $<0.05$ & $<0.05$ \\
\hline $\mathrm{Na}$ & $<0.01$ & $<0.01$ & $<0.01$ & $<0.01$ & $<0.01$ \\
\hline
\end{tabular}




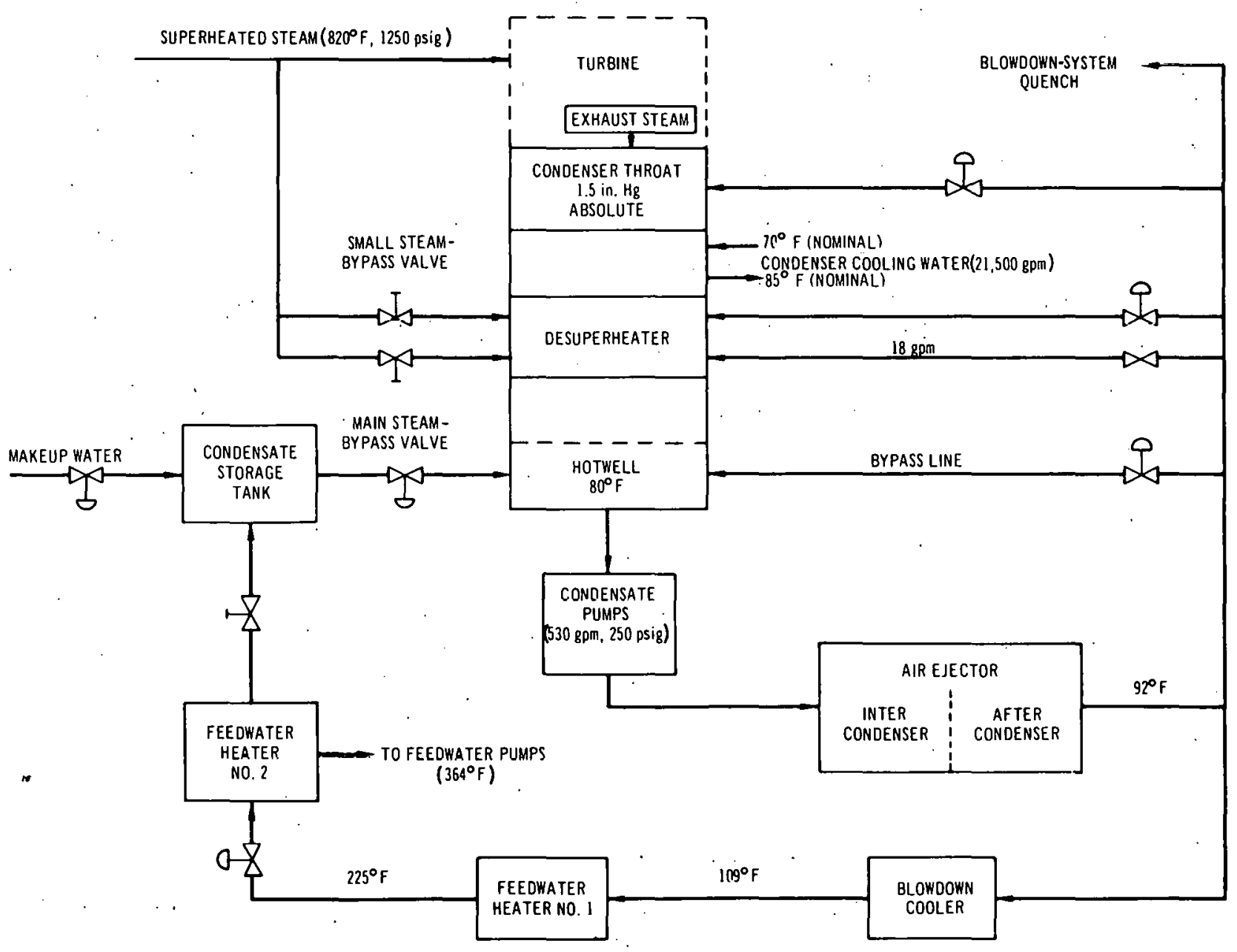

Fig. 3. Condensate Eyatem 


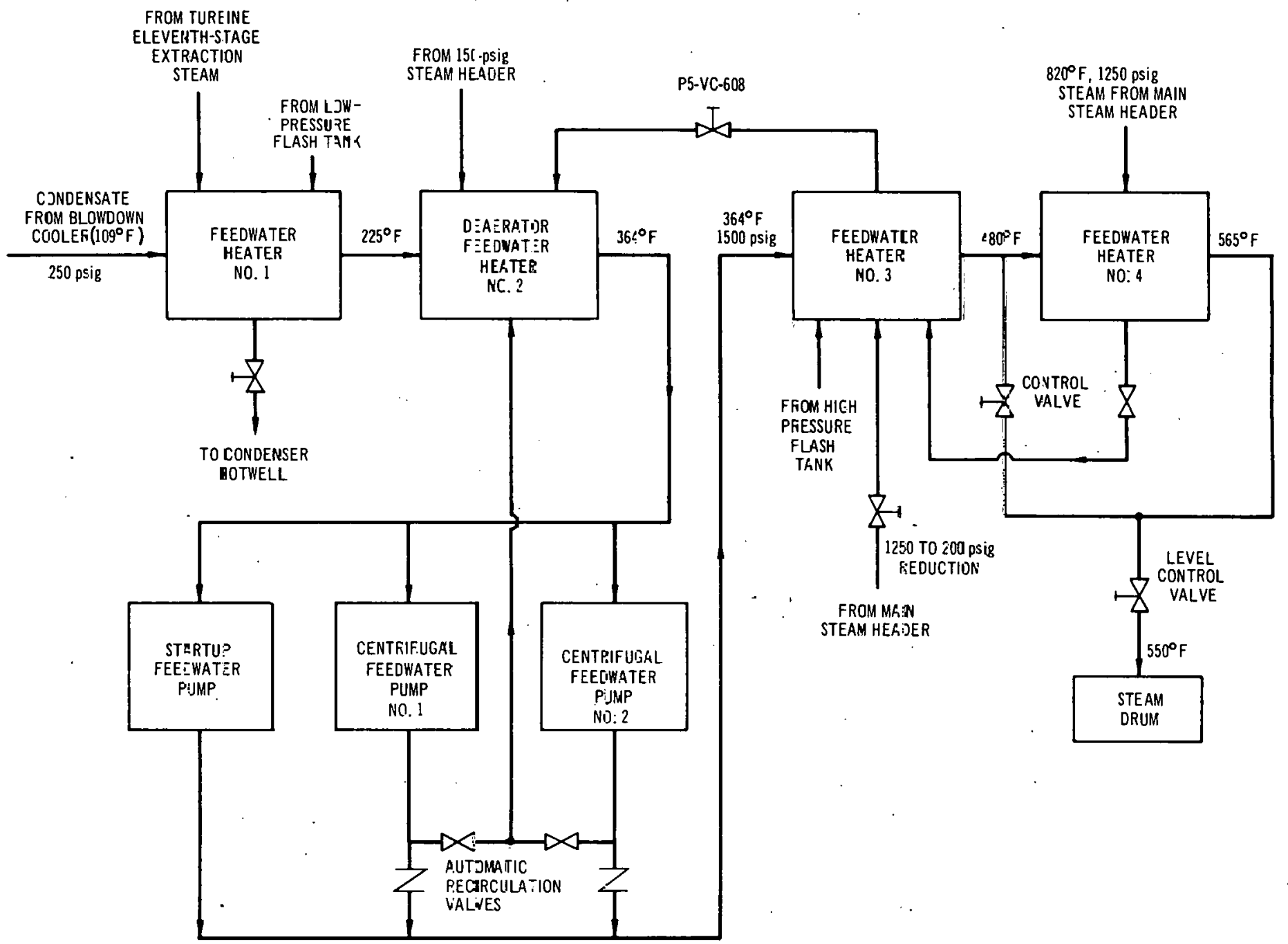

Fig. 4. Feedwater System 
a positive-displacement plunger-type pump coupled to a 75-hp gear motor, is used during low-demand conditions and will supply 30,000 1b/hr at 1300 psig. When demands exceed $30,000 \mathrm{lb} / \mathrm{hr}$, one of a pair of motor-driven multistage centrifugal pumps supplies feedwater. Normally, one pump operates while the other remains on standby. Either pump has sufficient capacity to supply the feedwater demand at full reactor power.

\section{Blowdown}

The blowdown system (Fig. 5) removes dissolved solids that build up in the steam drum. These impurities enter the steam drum with the feedwater. and, because they will not carry over with the steam, collect in the steam drum. The blowdown system consists of flash tanks that convert much of the water to steam, coolers that reduce the water temperature, filters to remove particulate material, and a demineralizer to remove dissolved impurities. Most of the heat loss of the blowdown water is used to heat feedwater.

\section{Makeup Water}

The makeup-water system supplies demineralized water of very high purity to the condensate storage tank to compensate for steam-system losses. Demineralized makeup water of lower purity is also supplied to the auxiliary boilers and other systems of the EBR-II.

\section{Cooling Water}

The cooling-water system supplies water for heat transfer to the main condenser and to other EBR-II components. It consists of three cooling-water systems--the condenser, reactor auxillaries system, and the plant--and two cooling towers. Cooling water makeup is raw well water.

\section{TREATMENT OF MAKEUP WATER AND BLOWDOWN}

Treatment of these two streams is similar in that they are both passed through ion-exchange beds to remove dissnlved solids. 


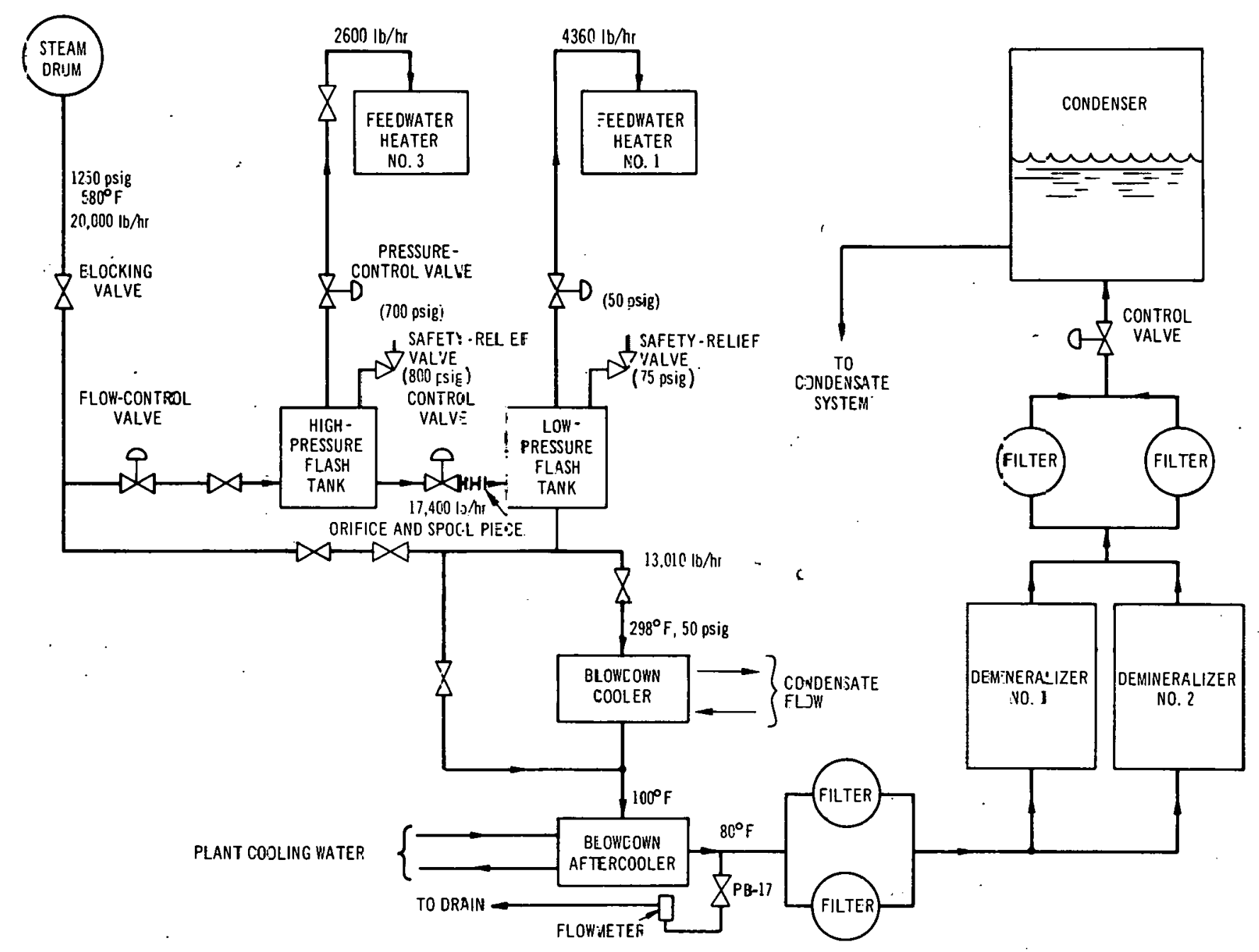

:ig. 5. Blowdown Systen 


\section{A. Makeup Water}

The treatment system for makeup water supplied demineralized water of very high purity to the condensate-storage tank to compensate for losses.

The raw water for the treatment is well water, an analysis of which is shown in Table II. The principal cations are calcium, magnesium, sodium, and potassium. The principal anions are chloride, sulfate, nitrate, and carbonate. The silica is present probably as very weakly ionized metasilicic acid.

The treatment system consists of primary and secondary demineralizers and regeneration equipment.

\section{Primary Demineralizers}

The primary demineralizers remove most of the dissolved minerals from the incoming raw water, producing demineralized water of relatively high purity for the influent of the secondary mixed-bed makeup demineralizers.

The demineralizer system is composed of two cation exchangers, a degasifier, two anion exchangers, and associated piping and equipment. The two cation and two anion exchangers permit uninterrupted demineralizing service. While one pair of cation-anion columns is in normal service, the alternative pair is regenerated and put in standby condition. The maximum service flow rate for each cation exchanger is $56 \mathrm{gpm}$ and that for each anion exchanger is $42 \mathrm{gpm}$. If more than $42 \mathrm{gpm}$ of demineralized water is required, the columns can be operated in parallel for a short time, until all columns are depleted. The columns are kept in service until 50,000 gal pass through the anion column or a breakthrough occurs. The $\mathrm{pH}$ and conductivity of the effluent from the anion column are continuously monitored.

\section{Secondary Demineralizers}

The secondary makeup demineralizer system consists of two mixed-bed demineralizers and the associated piping. These demineralizers "polish" part of the effluent from the primary anion column to produce demineralized water of very high purity for makeup to the power-plant condensate system. "Polish" means removing small amounts of ionic impurities that leak through the primary demineralizers. In the mixed-bed demineralizers, each column contains a homogenous mixture of cation and anion resins. The effluent from the deminer- 
TABLE II. Analysis of EBR-II Well Water

\begin{tabular}{lc}
\hline \multicolumn{1}{c}{ Constituent } & Amount, ppm \\
\hline Calcium & 30.0 \\
Magnesium & 12.0 \\
Sodium & 7.0 \\
Potassiun & 4.0 \\
Total Iron & $<0.005$ \\
Manganese & $<0.005$ \\
Chloride & 11.5 \\
Sulfate & 12.5 \\
Nitrate & 4.7 \\
Bicarbonate & 131.0 \\
Carbonate & 3.5 \\
Tree Carbon Dioxide & 4.7 \\
Silica & 32.5 \\
Total Hardness as $\mathrm{CaCO}_{3}$ & 123.5 \\
Total Electrolytes & 142.0 \\
Except SiO ${ }_{2}$ as CaCO $_{3}$ & 7.85 \\
pH & \\
\hline
\end{tabular}


alizer in service flows to the 5000-gal condensate-storage tank to provide makeup water on demand to the condensate system.

The mixed-bed columns have a service life of about 5,000,000 throughput gallons (about five years of service). Breakthrough is indicated by the effluent conductivity increasing to above the allowable maximum of 1.0 micromho/ $\mathrm{cm}$.

\section{Startup and Operation}

The makeup demineralizer system is started up by placing a cation column, the degasifier, an anion column, and a mixed-bed column in service to supply the condensate storage tank. The alternative columns are placed in standby. The system normally is in continuous operation.

\section{Regeneration of Columns}

The resins in the demineralizer columns are regenerated by acid or caustic.

The column resin is first treated with a salt solution to effectively load the anion resin with chloride and the cation resin with sodium. When the two resins are completely loaded, the cation resin will be much more dense than the anion resin, and the two will separate more easily during the backwash.

Next, the primary demineralizer colums are backwashed by upward passage of water to expand the resin bed and wash out any suspended solids carried into the bed by the influent. raw water. The cation columns are backwashed with raw water, anion columno with cation=column effluent. The backwashing rate must be carefu1.1.y regulated so that the upward flow is enough to properly loosen and clean the resin bed, yet not excessive so as to carry the resin out of the column.

Sulfuric acid is used to regenerate the cation resin. A $20 \%$ solution is prepared by diluting concentrated acid in a mixing tank. 'lihe solution is drawn from the mixing tank and injected into the line going to the cation exchanger by a water eductor, which operates on demineralized water from a primary anion exchanger. The water that operates the eductor, together with a water stream bypassing the eductor, further dilutes the acid solution. Flow rates of $20 \%$ arid solution and dilution water are adjusted to give the desired strength of regenerant acid solution to the cation exchanger. The cation regeneration 
is performed with regenerant acid of two different strengths. About $40 \%$ of the total amount of the sulfuric acid is injected into the cation exchanger as 2-3 solution. This two-step regeneration prevents deposition of sparingly soluble calcium sulfate in the resin and a resulting decrease in exchanger capacity. The first dilute-acid regenerant removes the bulk of the calcium ions from the bed as a very dilute solution of calcium sulfate; the sulfate ion concentration is low enough that the solubility of calcium sulfate is not likely to be exceeded. The second, stronger, acid solution completes regeneration of the resin without danger of calcium sulfate deposition. After the acid solution has been injected into the cation exchanger, the flow of dilution water is continued for a predetermined length of time to permit displacement of the acid downward through the resin bed:

After the displacement step, the cation exchanger is rinsed for thirty minutes with raw water at maximum flow, until the excess regenerant acid has been rinsed from the resin. After the rinse, the exchanger is ready for service.

Sodium hydroxide is used to regenerate the anion resin. A $20 \%$ caustic solution is drawn by gravity from the caustic storage tank and mixed with demineralized water in a mixing tank. This caustic solution is further diluted to a concentration of 5 to $7 \% \mathrm{NaOH}$ and injected into the anion exchanger by a water eductor operating on demineralized water. The dilution water is preheated by passage through a steam-heated exchanger to maintain the temperature of the diluted $\mathrm{NaOH}$ solution at $90-120^{\circ} \mathrm{F}$. The regenerant is heated to insure removal of the silica from the anion resin during the regeneration.

After the caustic has been injected into the anion exchanger, the flow of heated dilution water is continued so as to displace the regenerant caustic downward through the resin and complete the regeneration.

After the displacement step, cation-exchanger effluent is passed through the anion exchanger until excess caustic has been rinsed from the resin bed and the effluent conductivity matches a specification of about $20 \mathrm{micromhos} / \mathrm{cm}$.

\section{Effluent-water Quality}

Table III shows the effluent specifications. 
TABLE III.Specifications for Water from the Makeup System

\begin{tabular}{lll}
\hline Column & Analysis & Specification \\
\hline $\begin{array}{l}\text { Primary } \\
\text { Anion }\end{array}$ & $\mathrm{pH}$ & $7.8-8.8$ \\
$\begin{array}{l}\text { Primary } \\
\text { Anion }\end{array}$ & Conductivity & $\begin{array}{l}20 \mathrm{micromhos} / \mathrm{cm} \\
(\max )\end{array}$ \\
$\begin{array}{l}\text { Primary } \\
\text { Anion }\end{array}$ & Silica & 0.05 ppm (max) \\
$\begin{array}{l}\text { Secondary } \\
\text { Mixed-bed }\end{array}$ & Sodium & None specified \\
$\begin{array}{l}\text { Secondary } \\
\text { Mixed-bed }\end{array}$ & Silica & 0.01 ppm (max) \\
$\begin{array}{l}\text { Secondary } \\
\text { Mixed-bed }\end{array}$ & Chloride & $0.01 \mathrm{ppm}$ (max) \\
$\begin{array}{l}\text { Secondary } \\
\text { Mixed-bed }\end{array}$ & $\begin{array}{l}\text { Total } \\
\text { Hardness, } \\
\text { as CaCo }\end{array}$ & $0.05 \mathrm{ppm}$ (max) \\
\hline
\end{tabular}


B. Blowdown

\section{Treatment System}

The blowdown demineralizer system continuously removes impurities from the steam-drum blowdown to maintain high water quality in the steam system. It consists of two mixed-bed demineralizer columns, two inlet filters, two outlet filters, and associated piping and equipment.

During normal operation, one inlet filter, one demineralizer column, and one outlet filter are in operation, with the parallel units in standby.

When a demineralizer column becomes depleted (effluent conductivity. greater than 1 micromho/cm) the standby column is placed in service and the depleted column is regenerated.

Blowdown enters the inlet filter at $26 \mathrm{gpm}$ (maximum design rate, $52 \mathrm{gpm}), 50 \mathrm{psig}$, and 850F. The inlet filter removes undissolved particulate matter entrained in the blowdown, to prevent particulate fouling of the demineralizer resin bed. The flow then passes through the demineralizer resin bed, where Ionized materials are removed by ion exchange. The calcium carbonate is reduced from about $2 \mathrm{ppm}$ to less than $0.04 \mathrm{ppm}$. The final concentration of dissolved impurities is equivalent to a specific resistance of about 8 megohms $-\mathrm{cm}$ at $25^{\circ} \mathrm{C}$. The outlet filter removes any resin that escapes the column retention element.

Undissolved particulate matter in the blowdown consists mostly of magnetite $\left(\mathrm{Fe}_{3} \mathrm{O}_{4}\right)$, with small amounts of other constituents. Particulates larger than $15 \mu$ are filtered out by the system inlet filter. Small particulates travel on to be trapped by the demineralizer resin bed. Removal of the extremely fine magnetite from the resin bed requires a complicated backwash, using both air and water flow, before resin regeneration.

Two major soluble compounds in the steam-drum blowdown are morpholine $\left(\mathrm{C}_{4} \mathrm{H}_{9} \mathrm{NO}\right)$ and ammonia $\left(\mathrm{NH}_{3}\right)$ (see Treatment of Boiler Feedwater). These compounds and any traces of other ionized materials are removed by the demineralizer resin through ion exchange.

\section{Operation}

The blowdown demineralizers are maintained in operation in conjunction 
with the blowdown system during normal plant power operation.

The demineralizer column in service is operated until breakthrough occurs. The columns have a service life of about 600,000 throughput gallons (approximately 15 days of plant operation). Breakthrough is indicated by effluent conductivity increasing to greater than the allowable maximum of 1.0 micromho/cm.

\section{TREATMENT OF BOILER FEEDWATER}

Normally, feedwater contains no solid impurities because of the treatment of makeup water and blowdown in demineralizers. Therefore, control of dissolvedoxygen content and of $\mathrm{pH}$ is the routine treatment.

\section{A. Treatment System}

Chemical treatment of feedwater consists of adding hydrazine $\left(\mathrm{N}_{2} \mathrm{H}_{4}\right)$, primarily as an oxygen scavenger, and morpholine $\left(\mathrm{C}_{4} \mathrm{H}_{9} \mathrm{NO}\right)$, to control $\mathrm{pH}$.

Use of such volatile treatment agents as hydrazine and morpholine that have reaction products that are volatile or form water is defined as a "zerosolids" treatment.

Hydrazine is injected into the effluent from feedwater heater No. 2 (deaerator) to react with traces of dissolved oxygen remaining in the deaerated boiler feedwater.

Morpholine is injected into the effluent from the No. 2 feedwater heater to supplement the ammonia resulting from thermal decomposition of hydrazine and thus control the $\mathrm{pH}$ of the power-cycle streams at $8.8-9.2$. Use of morpholine is desirable because it provides better corrosion protection than ammonia to surfaces exposed to wet steam and condensate. This difference results from the "distribution ratio" of morpholine being much lower than that of ammonia under power-cycle conditions. The distribution ratio is defined as the ratio of the concentration of the $\mathrm{pH}$ additive in the steam to its concentration in the condensate formed. Ammonia, in the temperature range of interest, has a distribution ratio of about 7 - 10; morpholine has a ratio of about 0.4 . Thus, the morpholine tends to concentrate in the condensate, increasing its $\mathrm{pH}$ and providing protection to metals in contact with the condensate.

As long as the polishing demineralizers for makeup water are properly re- 
generated and monitored, contamination through makeup water is not likely. However, a condenser leak could occur at any time, and it becomes more probable as the plant ages. When a condenser leak is detected, the "zero-solids" feedwater treatment is suspended and phosphate-caustic treatment is used until the plant is shut down to repair the leak.

\section{Hydrazine Injection}

Hydrazine solution is prepared at the desired concentration (1.5\%) in a 30-gal stainless steel tank by diluting a concentrated solution( $35 \%$ ) of the hydrate $\left(\mathrm{N}_{2} \mathrm{H}_{4} \oplus \mathrm{H}_{2} 0\right)$ from the shipping container with demineralized water. Either of the two hydrazine-injection pumps takes hydrazine solution from this tank and delivers the solution, through the discharge piping, into the effluent line from feedwater heater No. 2. Normally, one pump is in operation while the other is maintained as a standby. Discharge rate of the pump in operation is manually adjusted to maintain the specified concentration $(0.01-0.02 \mathrm{ppm})$ in the feedwater.

Complete removal of dissolved oxygen from the feedwater is essential to minimize corrosion in the high-pressure feedwater heaters, evaporators, superheaters, and steam system. The chemical reaction for oxygen removal is:

$$
\mathrm{N}_{2} \mathrm{H}_{4}+\mathrm{O}_{2} \longrightarrow 2 \mathrm{H}_{2} \mathrm{O}+\mathrm{N}_{2} \text {. }
$$

Under boiler conditions, hydrazine thermally decomposes to ammonia:

$$
\begin{aligned}
& \underset{2}{2 \mathrm{~N}_{2} \mathrm{H}} \underset{\text { Heat } \longrightarrow}{\longrightarrow}{ }^{2 \mathrm{NH}_{3}+\mathrm{N}_{2}+\mathrm{H}_{2} ; \text { or }} \\
& 3 \mathrm{~N}_{2} \mathrm{H}_{4} \ldots \text { Heat } \rightarrow 4 \mathrm{NH}_{3}+\mathrm{N}_{2} \text {. }
\end{aligned}
$$

The ammonia formed increases the $\mathrm{pH}$ of the water in the power cycle (condensate, feedwater, and steam). Ammonia can corrode copper-bearing alloys such as admiralty-metal condenser tubes; therefore, the concentration of hydrazine in the feedwater must be closely controlled. The desired concentration in the feedwater, under full-power steam conditions, is $0.01-0.02 \mathrm{ppm}$. Higher hydrazine concentration is maintained in the feedwater during plant startup and shutdown to establish the proper concentration of residual hydrazine in the 
system and to guard against excessive oxygen in the feedwater.

Hydrazine concentration in the feedwater is monitored by an analyzerrecorder.

Oxygen concentration in effluent from the No. 2 feedwater heater is monitored by an analyzer-recorder. Free oxygen in the deaerator effluent is normally undetectable, or near zero. However, continuous monitoring of the deaerator effluent will warn if hydrazine injection should fail and not be detected otherwise or if a serious upset occurs in the deaerator operation.

For normal operation the hydrazine-injection system is placed in operation whenever feedwater is flowing to the steam drum.

Hydrazine is injected directly into the condenser hotwell if the normal hydrazine system malfunctions and cannot be restored to service.

\section{Morpholine Injection}

The condensate $\mathrm{pH}$ is controlled within the specified range (8.8 9.2) by intermittent operation of the morpholine injection pump. By maintaining the condensate $\mathrm{pH}$ within the specified range, the $\mathrm{pH}$ of the other systems (steam, feedwater, and blowdown) will follow and be controlled in a slightly wider $\mathrm{pH}$ range $(8.6-9.4)$.

The morpholine-injection system is manually started when the condensate $\mathrm{pH}$ is less than 8.8 and stopped when the $\mathrm{pH}$ reaches 9.2 .

\section{B. Procedures During Plant Operation}

\section{Startup}

Water-treatment operations during startup are described below.

a. Filling Condensate System With Treated Water

Hydrazine and morpholine are added to the condenser hotwell to provide treated water for filling the condensate and feedwater systems.

b. Filling the Feedwater System

The water from the condensate system contains hydrazine and morpholine added either during previous plant operation or during filling of the condensate system. Additional hydrazine is injected to assure enough excess during initial operation. 
c. Filling the Feedwater and Blowdown-system Yard Piping

Hydrazine is injected during the filling to assure a substantial

excess.

d. Heating Heater No. 2 and the Yard Piping for the Feedwater and Blowdown Systems

Hydrazine is determined at the feedwater sampling station. The hydrazine content of the feedwater and the $\mathrm{pH}$ of the condensate are controlled in the range specified for normal operation, except that a wider range of hydrazine is permitted $(0.01-0.10 \mathrm{ppm})$.

e. Filling the Steam Generator with Treated Water

The wacer concains hydrazlne and morpholine from previous treatment. Additional hydrazine is injected during filling to assure enough excess during initial operation. No morpholine is injected during this operation.

f. Heatup of Steam System to $350^{\circ} \mathrm{F}$

During system heatup, hydrazine is injected continuously whenever feedwater is flowing to the steam generator. The $\mathrm{pH}$ of the condensate is monitared and controlled at $8.8-9.2$ by morpholine injection.

g. Heatup from $350^{\circ} \mathrm{F}$ to Standby Condition at $580^{\circ} \mathrm{F}$

This operation is normally performed with the steam generator "bottled up"; i.e., without steam, feedwater, or blowdown flow (after a steamdrum water level has been established). No chemical injection is required.

\section{Normal Power Operation}

a. $\mathrm{pH}$ and Conductivity Monitoring

Sampling stalions 3-1 Llisuugh 3=6 (see Sampling and Munllorlng System) are maintained in service with the power cycle; $\mathrm{pH}$ and conductivity are recorded. The conductivity-sample streams of stations $\mathrm{s}-1, \mathrm{~S}-2, \mathrm{~s}-4, \mathrm{~s}-5$, and S-6 are processed through cation exchange columns.

The $\mathrm{pH}$ of the power-cycle streams depends on the concentrations of ammonia (from $\mathrm{N}_{2} \mathrm{H}_{4}$ decomposition) and morpholine in the water. If the hydrazine concentration used for oxygen scavenging is closely controlled, morpholine can be used to control $\mathrm{pH}$ within the desired range. If the $\mathrm{pH}$ increases above the control range with the normal hydrazine injection rate, the morpholine feed rate is reduced by intermittent operation or by adjusting the stroke of the injection pump. 
If the conductivity of the condensate (S-1), or blowdown ( $(S-4)$ sample stream exceeds 1.0 micromho/cm after passage through the cation exchanger, condenser leakage is suspected. However, the possibility of malfunction of the conductivity system or breakthrough of the cation exchanger is first investigated.

\section{b. Hydrazine and Oxygen Monitoring}

The analyzers for hydrazine and dissolved oxygen in service monitor the feedwater (S-5) hydrazine residual, and oxygen in the deaerator effluent $(S-2)$.

The concentration of dissolved oxygen in the effluent from a properly operating deaerator normally does not exceed $0.007 \mathrm{ppm}$. If the dissolved-oxygen analyzer indicates this concentration, a malfunction affecting deaerating efficiency is suspected and deaerator operating conditions are checked.

A hydrazine residual of $10-20 \mathrm{ppb}$ in the feedwater normally provides ample excess for scavenging traces of oxygen remaining in the deaerator effluent. The injected hydrazine concentration is maintained at least 1.5 times the indicated oxygen content of the deaerator effluent.

\section{Plant Shutdown}

As reactor power is decreased, the hydrazine and morpholine feed rates are decreased to maintain the specifications for $\mathrm{pH}$ and hydrazine residual in feedwater as for normal operation.

\section{Plant Standby}

The hydrazine injection pump is operated at tuil stroke whenever a feedwater pump is operated to adr fepdwater to the steam drum.

\section{Plant Cooldown}

During cooldown from $700^{\circ} \mathrm{F}$ to $580^{\circ} \mathrm{F}$, the hydrazine and morpholine feed rates are proportioned to feedwater flow to maintain normal $\mathrm{pH}$ and 
hydrazine residual in feedwater.

During cooldown from $580^{\circ} \mathrm{F}$ to $350^{\circ} \mathrm{F}$, sampling stations $\mathrm{S}-2$ through S-6 are secured. Station S-1 (condensate) is kept in operation for monitoring $\mathrm{pH}$ and conductivity. Hydrazine injection is continued.

If the steam generator is to be put in dry layup, hydrazine injection is continued during cooldown from $340^{\circ} \mathrm{F}$ to ambient temperature. If the steam generator is to be placed in wet layup, the water is heavily treated with hydrazine and morpholine during final recirculation.

6. Inleakage of Condenser Cooling Water

If a leak, such as a condenser-tube failure that would allow condenser cooling water to enter the hotwell occurs, the conductivity recorder will indicate an increase in conductivity proportional to the size of the leak. Normal conductivity will be $0.2-0.5 \mathrm{micromhos} / \mathrm{cm}$. An increase in conductivity to more than 1 micromho/cm requires a check for cooling-water inIcalkage.

When the inleakage is confirmed, the blowdown demineralizer is taken out of service and phosphate injection is begun. After the condenser leak has been eliminated, the "zero-solids" treatment is resumed.

a. Specifications for Operation with Leakage of Condenser Cooling Water

$\begin{array}{ll}\text { (1.) Water Conditions (allowable range) } \\ \begin{array}{ll}\text { pH (fecdwatcr, condencatc; } \\ \quad \text { deaerator effluent, steam) }\end{array} & 9.3-9.5 \\ \text { Total solids (blowdown) } & 200 \mathrm{ppm} \text { (max) } \\ \text { Free OH (blowdown) } & 5-10 \mathrm{ppm} \\ \mathrm{PO}_{4} \text { (blowdown) } & 10-20 \mathrm{ppm} \\ \text { Chloride (blowdown) } & 5 \mathrm{ppm} \mathrm{(max)} \\ \text { pH (blowdown) } & 10.5-10.8 \\ \text { Hydrazine (feedwater) } & 0.01-0.02 \mathrm{ppm}\end{array}$

The blowdown system is kept in operation with the flow diverted to the drain. A flow of about $10 \mathrm{gpm}$ is established.

The limiting parameler for continued planl uperaliun is a maximum of 5 ppm chloride.

If blowdown is increased to $20,000 \mathrm{lb} / \mathrm{hr}$, and the chloride concentration cannot be kept below $5 \mathrm{ppm}$, the plant is shut down. The leak is too large for continued plant operation, because the maximum flow rate of the 
makeup demineralizer would be exceeded.

V. SAMPLING AND MONITORING SYSTEM

Water is sampled at six stations:

\begin{tabular}{|c|c|}
\hline $\begin{array}{l}\text { Station } \\
\text { Number }\end{array}$ & Stream Samples \\
\hline$s-1$ & Condensate-pump Discharge \\
\hline$s-2$ & Effluent from No. 2 Heater \\
\hline$s-3$ & Blowdown-demineralizer Effluent \\
\hline$s-4$ & Boiler Blowdown \\
\hline$s-5$ & Boiler Feedwater \\
\hline$s-6$ & Condensed Steam \\
\hline
\end{tabular}

\section{A. Components and Operation}

A sampling line runs from the stop valve at each sampling point to the corresponding sampling station. Stop valves, throttle valves, sample coolers, thermometers, pressure gauges, and pressure regulators are included in the sample-conditioning portions of the sampling stations. Figure 6 is a block diagram of a typical station. Each station includes flow cells for measuring electrolytic conductivity and $\mathrm{pH}$, throttling valves for flow adjustment, and provision for taking "grab" samples for laboratory analysis.

Analyzer-recorders, installed in the water-treatment area near the hydrazine injection pump, monitor dissolved oxygen and hydrazine. Sample flow from stations S-2, S-5, and $\mathrm{S}-6$ is provided to each analyzer. Flow from $\mathrm{S}-1$ is provided to the oxygen analyzer only. During normal operation, the hydrazine analyzer monitors station S-5 and the oxygen analyzer monitors station S-2.

Continuous $\mathrm{pH}$ monitoring recorded on the steam panel in the Main Control Room provides information on the distribution of ammonia, hydrazine, and . morpholine in the power cycle. To facilitate operator surveillance, an additional continuous-monitoring system was installed in the chemical-feed area.

The electrolytic conductivity of each major power-plant stream is also continuously recorded on the steam panel. This conductivity is an indirect measure 


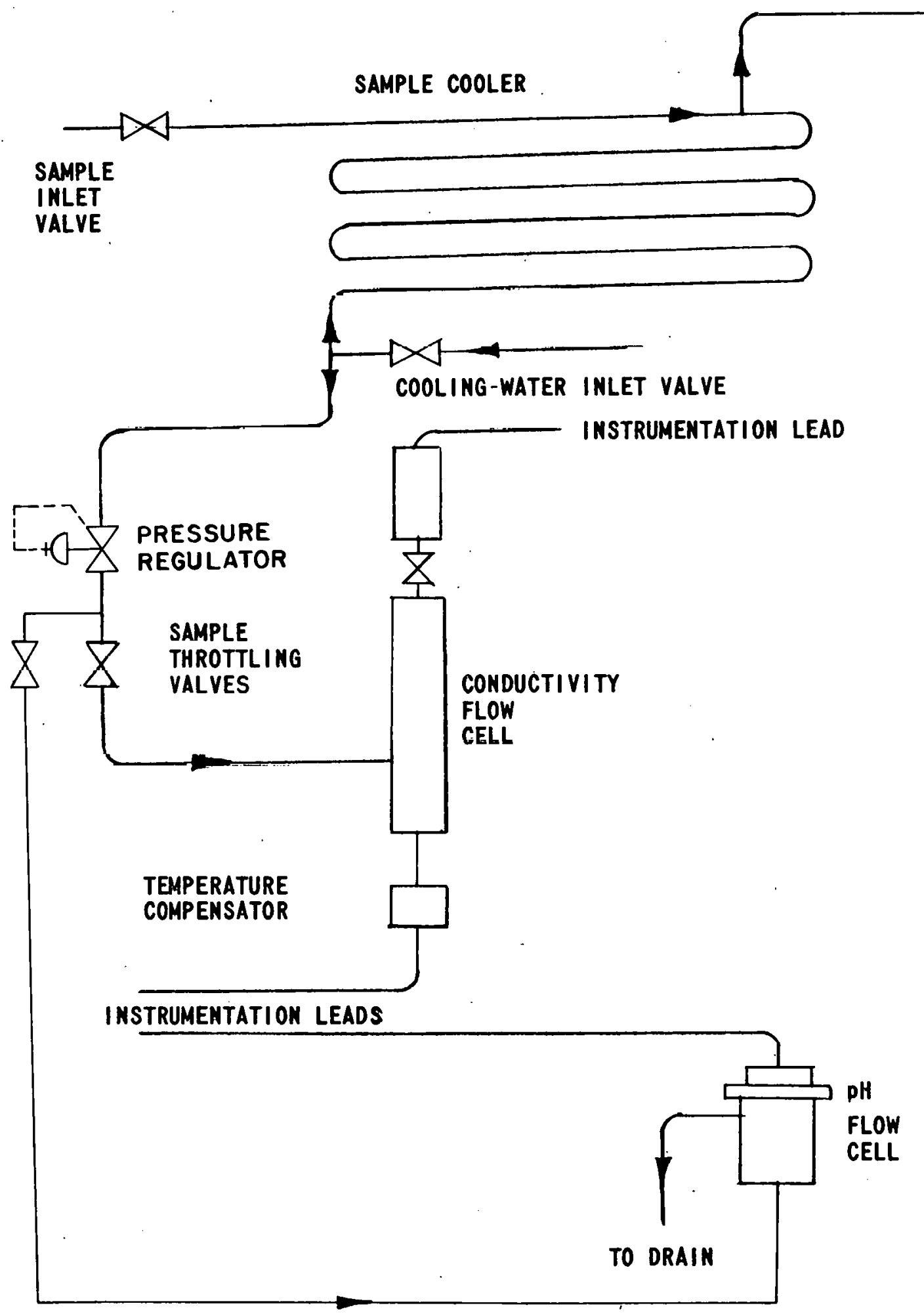

Fig. 6. Typical Water-sampling Station 
of the dissolved electrolytes but is nonspecific; that is, the type of electrolytes must be identified by chemical analysis. Nevertheless, conductivity is a useful indicator for gross contamination in the power cycle as, for example, by leakage of plant cooling water into the condensate.

Two general classes of substances present in the sample may increase the conductivity of the water. The first class comprises hydrazine, morpholine, and ammonia. The other class comprises impurities such as $\mathrm{NaCl}, \mathrm{H}_{2} \mathrm{SO}_{4}, \mathrm{Na}_{2} \mathrm{Cr}_{2} \mathrm{O}_{7}$, , and $\mathrm{II}_{2} \mathrm{CO}_{3}$, which would originate from a leak of condenser cooling water, faulty operation of the demineralizers, air inleakage, or other sources.

To measure conductivity due to dissolved salts (e.g.,sodium chloride), the sample streams for conductivity measurement are passed through strongly actdic cation exchangers. These remove ammonia, hydrazine, and morpholine and convert dissolved salts to the corresponding acids ( $\mathrm{HCl}$ and $\mathrm{H}_{2} \mathrm{SO}_{4}$ ). The effect is to remove "background" conductivity due to the bases, and to "amplify" conductivity of dissolved salts. Thus, an increase in "cation-exchanger conductivity" would indicate an increase in inorganic electrolytes, such as could result from leakage of cooling water into the condenser. Such a conductivity increase is rapidly investigated.

A cation-exchange column, containing strongly acidic cation-exchange resin, is in each of the sampling stations for condensate, No. 2 heater, feedwater, blowdown, and condensed steam. The unit detects the presence, and a change in the concentrations, of electrolytes in the sample as read with an electrolytic conductivity bridge. The bridge and recorder are mounted in the steam panel in the control room.

When a sample containing hydrazine, morpholine, or ammonia is passed through a bed of strongly acidic cation-exchange resin, the bases are held by the resin, and hydrogen ions are released that combine with the hydroxyl ions from the bases to form water. The electrolytic conductivity contributed by the bases is thus removed.

When dilute solutions of inorganic salts are passed through a bed of strongly acidic cation-exchange resin, the cation is held by the resin and a hydrogen ion is released which remains as an ion. The hydrogen ion, as well as the anion from the impurity, contributes to electrolytic conductivity of the sample. Therefore, an increase in the conductivity of the sampling station cation exchanger effluent above routine operating levels would indicate an abnormal condition. 
B. Schedules

Water streams are routinely sampled as shown below, for laboratory analysis from stations $S-1, S-2, S-4$, and $S-5$, at the same time during steady-state plant conditions to permit comparison of results. The analyses are performed once per shift for control purposes.

1. Condensate (Samp1ing Station S-1)

a. $\mathrm{pH}$ (grab sample) Once per shift

Ammonia

Morpholine

Chloride

Once per numbered reactor run

Total Hardneco

Iron

Copper

2. Deaerator Effluent (Sampling Station S-2)

Dissolved Oxygen Once per day

(Indigo carmine)

3. Blowdown (Sampling stacion S-4)

Ammonia

vionrpho11ne

Chloride

Once per numbered reactor run

Total Hardness

Silica

Iron

Copper

4. Boiler Feedwater (Sampling Station S-5)

$\mathrm{pH}$ (grab sample) Once per shift

Hydrazine (photometer) Once per shift

Dissolved Oxygen Once per day

(Indigo carmine) 
Ammonia

Morpholine

Chloride

Total Hardness

Silica

Iron

Copper
$\mathrm{pH}$ (grab sample)

Ammonia

Morpholine

Chloride

Total Hardness

Silica
Once per numbered reactor run

Once per day

\}

Once per numbered reactor run

6. Makeup Feedwater (Polishing Demineralizer Effluent)

Sodium Chloride

Total Hardness

Silica
Once per numbered reactor run

\section{Analytical Data}

Appendix A shows typical data recorded during steam-plant operation.

VI. HISTORY OF WATER TREATMENT FOR EBR-II

A. Installation, Preconditioning, and Chemical Cleaning

After installation in March 1962, the steam generator was filled with

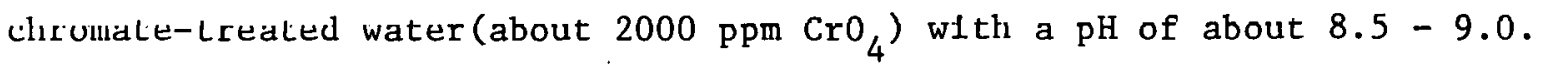

The concentration of chromate inhibitor was maintained during hydrostatic testing of the steam generator and feedwater lines in June 1962.

Before chemical cleaning in August 1962, the chromate inhibitor was removed and the system flushed with demineralized water.

The system was chemically cleaned by circulating a hot $\left(200^{\circ} \mathrm{F}\right)$ alkaline detergent through the system, then an inhibited organic acid solution (at $200^{\circ} \mathrm{F}$ ) 
to remove rust and mill scale. After the system was flushed with demineralized water visual inspection of the steam drum and internal parts indicated satisfactory removal.

The system was placed in wet layup with water containing $5000 \mathrm{ppm} \mathrm{CrO}_{4}$ $(\mathrm{pH}$ of $8.5-10.0)$. Wet layup continued until January 1963, when the chromate solution was drained and the steam generator was flushed with demineralized water. The steam system and associated piping were filled with demineralized water treated with trisodium phosphate to maintain $\mathrm{pH}$ at $9.5-10.5$. Sodium sulfite (25-100 ppm) was added for oxygen control.

B. Prepower, Hot Operacton, and Wet Crlticallity

During system heatup to $330^{\circ} \mathrm{F}$, treatment with sultite and trisodium phosphate was maintained until September 1963.

Preparatory to heating above $350^{\circ} \mathrm{F}$, treatment with trisodium phosphatc was discontinued and sulfite concentration was limited to 5-10 ppm. During wet 1 ayup the water was treated with hydrazine and morpholine.

During heatup from $350^{\circ} \mathrm{F}$ to $570^{\circ} \mathrm{F}$ in November 1963 , the evaporators and superheaters were maintained in a flooded condition

In the same month, the system was cooled to ambient temperature. The steam generator was placed in wet layup, with the water containing hydrazine, morpholine, and $120 \mathrm{ppm}$ sodium sulfite.

Wet layup continued until April 1964, until heatup to $575^{\circ} \mathrm{F}$. Addition of sodium sulfite was discontinued after heatup above $350^{\circ} \mathrm{F}$.

Wet layup continued until Junc, with 150 ppm sodium sulfite and morpholine bo coulEOL $\mathrm{fH}$ il 10.2 .

\section{Approach to Power Operation}

In June 1964 , heatup to $575^{\circ} \mathrm{F}$ and 1270 psig operation was started. Approach to power operation started in July and continued until August, when the plant was shut down.

Wet layup continued until October, when power operation was started again.

In November, the steam system was placed in wet layup, with the water containing $1300 \mathrm{ppm} \mathrm{CrO}_{4}$ and at a pH of 9.3. Wet layup continued until February 1965, when the chromate was drained; the steam generator was flushed with de- 
mineralized water; and demineralized water, at a $\mathrm{pH}$ of 10 and containing 2000 ppm morpholine, was used to fill the steam generator.

D. Water Leak at Tube-to-Tubesheet Weld

In February 1965, before hydrostatic testing, a water leak was found in the air space between the water and sodium tubesheets of one of the evaporators. The steam system was drained and dried. The riser pipe was cut in two places for access to the steam tubesheet for weld repair. The leak was welded and the evaporator returned to service in March 1965.

The steam generator was filled with demineralized water with $2000 \mathrm{ppm}$ hydrazine and 2000 ppm morpholine added.

Plant operation started in March 1965. Normal feedwater treatment with hydrazine and morpholine was begun.

\section{E. Leak in Main-condenser Tube}

In May 1971, blowdown conductivity increased slightly. In October, the conductivity increased to $50 \mathrm{micromho} / \mathrm{cm}$ and sodium-ion electrodes indicated an increase of sodium ion from $1 \mathrm{ppb}$ to $200 \mathrm{ppb}$. Hardness increased appreciably. The leak rate was estimated at $1 \mathrm{gal} / \mathrm{hr}$. The leak was discovered in a tube with a hole 1/2-in. long and 1/16-in. wide. The cause of the leak was erosion by condensate returning to the condenser via the minimum-flow valve. Slight damage was noted in adjacent tubes. The leaking tube and 10 other tubes with slight erosion damage were plugged.

After repair and a leak test, the system was returned to service in December 1971.

\section{F. Inspections of Evaporator and Steam Drum}

Evaporator 702 is the only evaporator of the eight in service that has been inspected. Inspecting the other evaporators or superheaters would require cutting the risers and downcomers for access to the steam tubesheet.

The evaporator was inspected to determine the effectiveness of the chemical treatment and the condition of the internal surfaces of the steam drum, risers, tubesheet, and the bore side of evaporator tubes. 
This evaporator was first inspected during the repair of the leak in the tube-to-tubesheet. Subsequent inspections were made in January 1969, December 1970, May 1972, April 1973, and May 1974.

The steam drum is inspected at the same time the evaporator is. The steam drum is made available for inspection during shutdown by opening the manhole cover on both ends.

\section{Methods}

The inspections are visual, for evidence of gross corrosion, pitting corrosion, scale formation, and the extent of accumulation and deposition of corrosion products.

The tube internals are viewed with a borescope and photographs are taken through the borescope for examination and comparison with previous inspections. Visual observations are made, and photographs of the steam drum and tube sheet are taken for examination añd comparison with previous inspections. Samples of corrosion products are removed from the internal surfaces and analyzed for composition and comparison with previous inspection analyses. Corrosion coupons exposed in the steam drum in the steam phase and the water phase are removed and examined for evidence of corrosion. Visual observations and weight-change data are compared with previous inspections.

\section{Resu1ts}

Generally all metal surfaces are covered with brown-red magnetic iron oxide. The deposits vary from light to 1/16-in. thickness. The outer layer is a light porous coating, easily removed by brushing; the inner deposit is a more adherent, dense film. There is no evidence of pitting or metal loss when the deposits are removed. Loose deposits accumulate on horizontal surfaces, such as piping, separators, and the tubesheet.

No appreciable change has been detected in the metal surfaces of the steam-drum internals, separators, riser walls, tubesheet, or tube interior from one inspection to the next.

After surfaces were brushed to remove the light deposits in the evaporator tubes, fabrication marks, both axial and circumferential, could be seen through the borescope. Some surface irregularities and shallow pits were 
observed, with depths up to about $5 \mathrm{mils}$.

The first 15 in. of tube length of the evaporator tubes is covered with a thin, fine-grained deposit of iron oxide. The next 8-9 ft. appears crystalline as seen through the borescope. The crystalline appearance disappears gradually down the tube length.

Corrosion coupons installed in the steam drum in the water and steam showed little change in appearance or in weight change from previous inspections. Mill marks and stamped numbers are sharp and showed little evidence of corrosion.

Table IV lists a typical analysis of deposits removed from the evaporator.

The high copper content is typical of deposits from systems having condensers with tubes of a high-copper alloy.

The nickel source is stainless steel components in the condensate system and air ejectors.

The high-calcium depostt in the tubes, which occurs in the high- . temperature zone of the evaporator, could result from precipitation at operating temperatures of trace amounts of calcium in the feedwater or from the condenser-tube leak in May 1971.

\section{CONCLUSION}

The EBR-II steam-generating plant has accumulated over 85,000 hours of in-service operation and has operated successfully for over ten years with the zero-solids treatment.

Inspection of the steam drum, evaporator, and other plant components on the steam and water sides shows the surfaces to be in excellent condition with minimal corrosion. Total corrosion is estimated from corrosion products to be less that $0.1 \mathrm{mil}$ of the heat-transfer surfaces. 
TABLE IV Analyses of Deposits in Evaporator Tubesheets and Tubes

\begin{tabular}{lcc}
\hline Element & Tubesheets & Tubes \\
\cline { 2 - 3 } Iron & 10.5 & 18.1 \\
Chromium & 0.6 & 0.2 \\
Nicke1 & 4.8 & 7.5 \\
Copper & 29.2 & 32.0 \\
Molybdenum & $240 \mathrm{ppm}$ & $<0.12$ \\
Manganese & 0.3 & 0.15 \\
Calcium & 0.9 & 21.7 \\
Tin & 0.13 & $<0.6$ \\
\hline
\end{tabular}




\section{APPENDIX}

Tables V-X show typical results of analyses in the steam-water system of EBR-II. 
TABLE $V$. Hydrazine and Dissolved Oxygen in Feedwater and Heater No. 2 for Run 40

\begin{tabular}{|c|c|c|c|c|c|}
\hline \multirow{2}{*}{\multicolumn{2}{|c|}{ Date }} & \multirow[b]{2}{*}{ Hydrazine in Feedwater } & \multirow[b]{2}{*}{$\mathrm{ppm}$} & \multicolumn{2}{|c|}{ Dissolved Oxygen, $\mathrm{ppb}$} \\
\hline & & & & No. 2 Heater & Feedwater \\
\hline February & 1 & 0.02 & & -- & -- \\
\hline$(1970)$ & 2 & 0.02 & & 22 & -- \\
\hline . & 3 & 0.02 & & 15 & $<5$ \\
\hline & 4 & 0.03 & & 22 & -- \\
\hline & 5 & -- & & 22 & -- \\
\hline & 6 & 0.05 & & 22 & -- \\
\hline & 7 & 0.04 & & - & - \\
\hline & 8 & 0.03 & & -- & -- \\
\hline & 9 & 0.03 & & 22 & $<5$ \\
\hline & 10 & 0.03 & & -- & -- \\
\hline & 11 & 0.02 & & 15 & $<5$ \\
\hline & 12 & 0.02 & & 22 & $<5$ \\
\hline & 13 & 0.03 & & 15 & $<5$ \\
\hline & 14 & -- & & -- & -- \\
\hline & 15 & -- & & -- & - \\
\hline & 16 & 0.01 & & 15 & $<5$ \\
\hline & 17 & 0.03 & & 22 & 5 \\
\hline & 18 & 0.03 & & 15 & $<$ \\
\hline & 19 & 0.01 & & 22 & $<5$ \\
\hline & 20 & 0.06 & & 22 & $<5$ \\
\hline & 21 & 0.04 & & -- & -- \\
\hline & 22 & 0.04 & & -- & -- \\
\hline & 23 & 0.03 & . & 15 & 5 \\
\hline & 24 & 0.04 & & 22 & $<5$ \\
\hline & 25 & 0.03 & & 15 & $<5$. \\
\hline & 26 & 0.02 & & 15 & $<5$ \\
\hline & 27 & 0.03 & & 22 & $<5$ \\
\hline & 28 & 0.03 & & - & -- \\
\hline March & 1 & 0.02 & & -- & $\ldots \ldots$ \\
\hline
\end{tabular}


TABLE VI. Hydrazine and Dissolved Oxygen in Feedwater and Heater No. 2 for Run 44

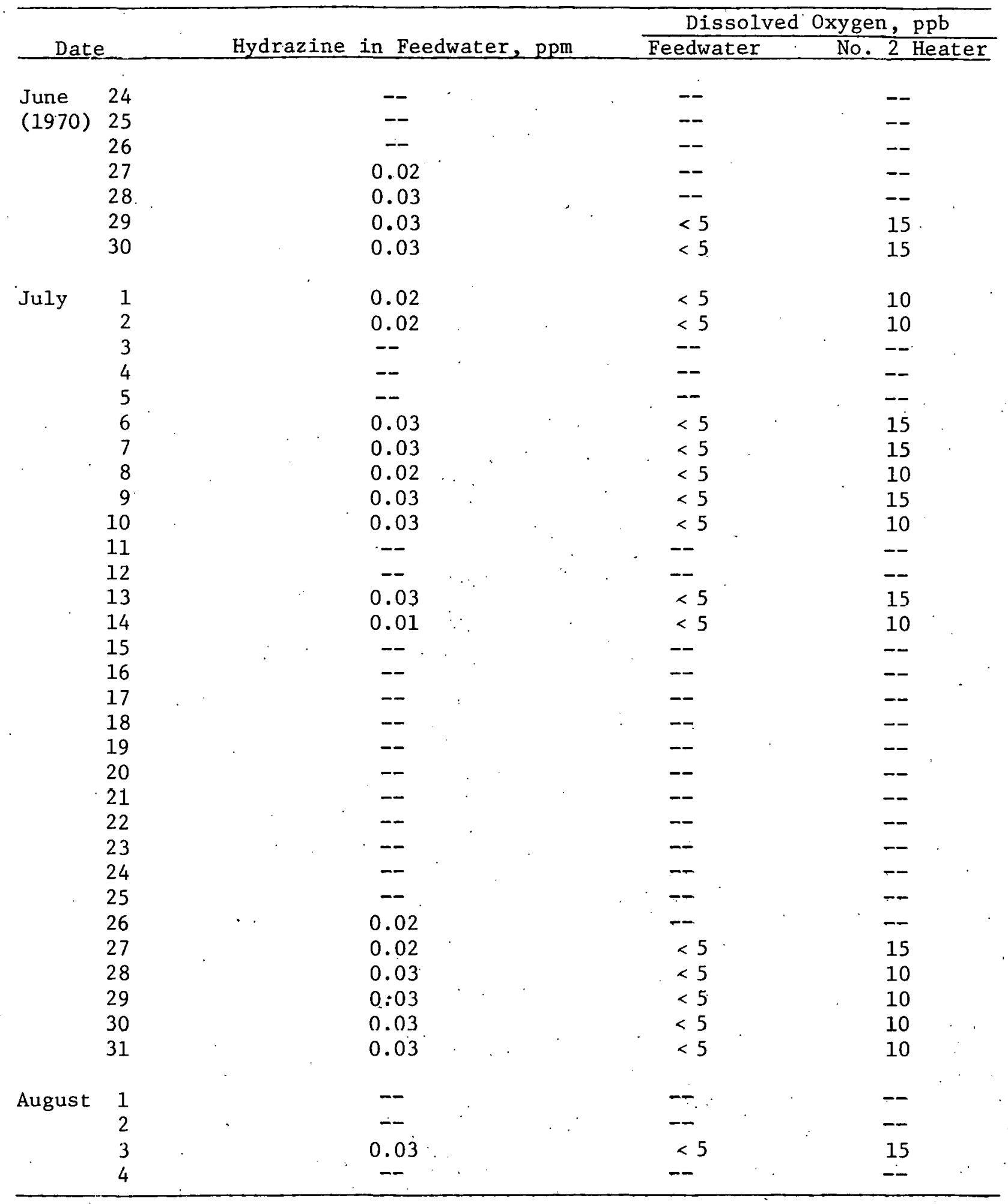


TABLE VII. Spectrophotmetric Analysis of Steam-Feedwater System for Run 40 (ppm)

\begin{tabular}{|c|c|c|c|c|c|c|c|c|}
\hline Week of & $\mathrm{NH}_{3}$ & $\mathrm{Cl}$ & $\mathrm{Cu}$ & Morpholine & $\mathrm{Fe}$ & $\mathrm{SiO}_{2} \mathrm{HI}$ & azine & e Hard \\
\hline \multicolumn{9}{|l|}{ Feb 3-9 (1970) } \\
\hline Blowdown & -- & $<0.05$ & -- & 0.2 & -- & -- & -- & $<0.01$ \\
\hline Blowdown Demin & -- & $<0.05$ & - & $<0.1$ & -- & -- & -- & -- \\
\hline Condensate & -- & $<0.05$ & - & $<0.2$ & -- & -- & -- & $<0.01$ \\
\hline reedwater & -- & $<0.05$ & -- & $<0.2$ & -- & -- & 0.04 & $<0.01$ \\
\hline Makeup Demin & -- & $<0.05$ & -- & -- & -- & -- & - & $<0.01$ \\
\hline Steam & -- & $<0.05$ & -- & $<0.2$ & -- & -- & -- & $<0.01$ \\
\hline \multicolumn{9}{|l|}{ Feb $\quad 10-16$} \\
\hline Blowdown & 0.25 & $<0.05$ & - & 2.5 & -- & $<0.5$ & - & $<0.01$ \\
\hline Blowdown Demin & $<0.01$ & $<0.05$ & -- & $<0.1$ & -- & - & -- & _ \\
\hline Condensate & 0.60 & $<0.05$ & -- & 3.5 & -- & -- & -- & $<0.01$ \\
\hline Feedwater & 0.60 & $<0.05$ & - & 2.5 & -- & $<0.05$ & 0.04 & $<0.01$ \\
\hline Makeup Demin & -- & $<0.05$ & - & -- & -- & $<0.05$ & - & $<0.01$ \\
\hline Steam & 0.60 & $<0.05$ & - & 2.0 & -- & $<0.05$ & -- & $<0.0$ \\
\hline
\end{tabular}

Feb 17-23

$\begin{array}{lccccccccc}\text { Bluwduwı } & 0.21 & <0.05 & <0.05 & 0.3 & <0.005 & <0.05 & -- & \times 0.01 \\ \text { Blowdown Demin } & <0.01 & <0.05 & -- & <0.1 & - & - & - & -- \\ \text { Condensate } & 0.42 & <0.05 & <0.05 & 0.5 & <0.005 & - & - & <0.01 \\ \text { Feedwater } & 0.45 & <0.05 & <0.05 & 0.5 & <0.005 & <0.05 & 0.04 & <0.01 \\ \text { Makeup Dem1n } & -- & <0.05 & -- & -- & -- & <0.05 & \ldots- & <0.01 \\ \text { Steam } & 0.45 & <0.05 & -- & 0.5 & -- & <0.05 & -- & <0.01\end{array}$

Feb 24-March 2

$\begin{array}{lrrrrrrrr}\text { Blowdown } & 0.30 & <0.05 & <0.05 & 2.0 & <0.005 & <0.05 & -- & <0.01 \\ \text { Blowdown Demin } & <0.01 & <0.05 & -- & <0.1 & - & - & - & - \\ \text { Condensate } & 0.40 & <0.05 & <0.05 & 2.0 & <0.005 & - & - & <0.01 \\ \text { Feedwater } & 0.40 & <0.05 & <0.05 & 2.5 & <0.005 & <0.05 & 0.04 & <0.01 \\ \text { Makeup Demin } & -- & <0.05 & -- & -- & - & <0.05 & - & 0.01 \\ \text { Steam } & 0.50 & <0.05 & -- & 2.0 & - & <0.05 & - & 0.01\end{array}$


TABLE VIII. Spectrophotometric Analysis of Steam-Feedwater Systems for Run 42 (ppm)

\begin{tabular}{|c|c|c|c|c|c|c|c|c|}
\hline Week of & $\mathrm{NH}_{3}$ & $\mathrm{Cl}$ & $\mathrm{Cu}$ & Morpholine & $\mathrm{Fe}$ & $\mathrm{SiO}_{2}$ & Hydrazine & $\begin{array}{c}\text { Total } \\
\text { Hardness }\end{array}$ \\
\hline \multicolumn{9}{|l|}{ Apr 21-27 (1970) } \\
\hline Blowdown & 0.15 & $<0.05<$ & 0.05 & $<0.2$ & $<0.001$ & $<0.05$ & -- & $<0.01<0.01$ \\
\hline Blowdown Demin< & 0.01 & $<0.05$ & -- & $<0.1$ & - & -- & - & $--<0.01$ \\
\hline Condensate & 0.35 . & $<0.05<$ & $=0.05$ & $<0.1$ & $<0.001$ & -- & -- & $<0.01<0.01$ \\
\hline Feedwater & 0.60 & $<0.05<$ & $<0.05$ & $<0.1$ & $<0.001$ & $<0.05$ & 0.05 & $<0.01<0.01$ \\
\hline Makeup Demin & -- & $<0.05$ & -- & -- & -- & $<0.05$ & - & $<0.01<0.01$ \\
\hline Steam & 0.80 & $<0.05$ & -- & 0.2 & - & $<0.05$ & - & $<0.01<0.01$ \\
\hline \multicolumn{9}{|l|}{ Apr 28-May 4} \\
\hline Blowdown & 0.15 & $<0.01<$ & $=0.05$ & $<0.1$ & $<0.005$ & $<0.1$ & - & $<0.01<0.01$ \\
\hline Blowdown Demin < & 0.01 & $<0.01$ & -- & $<0.1$ & -- & -- & -- & $--<0.01$ \\
\hline Condensate & 0.25 & $<0.01<$ & $=0.05$ & $<0.1$ & $<0.005$ & -- & -- & $<0.01<0.01$ \\
\hline Feedwater & 0.30 & $<0.01<$ & 0.05 & $<0.1$ & $<0.005$ & $<0.1$ & 0.02 & $<0.01<0.01$ \\
\hline Makeup Demin & -- & $<0.01$ & -- & -- & -- & $<0.1$ & -- & $<0.01<0.01$ \\
\hline Steam & 0.30 & $<0.01$ & -- & $<0.1$ & -- & $<0.1$ & -- & $<0.01<0.01$ \\
\hline \multicolumn{9}{|l|}{ May 5-11 } \\
\hline Blowdown & 0.25 & $<0.01<$ & 0.05 & $<0.1$ & $<0.005$ & $<0.05$ & - & $<0.01<0.01$ \\
\hline Blowdown Demin < & 0.01 & $<0.01$ & -- & $<0.1$ & -- & -- & -- & $--<0.01$ \\
\hline Condensate & 0.40 & $<0.01<$ & 0.05 & $<0.1$ & $<0.005$ & - & -- & $<0.01<.0 .01$ \\
\hline Feedwater & 0.40 & $<0.01<$ & 0.05 & $<0.1$ & $<0.005$ & $<0.05$ & 0.04 & $<0.01<0.01$ \\
\hline Makeup Demin & - & $<0.01$ & -- & -- & - & $<0.05$ & -- & $<0.01<0.01$ \\
\hline Steam & 0.30 & $<0.01$ & -- & $<0.1$ & - & $<0.05$ & -- & $<0.01<0.01$ \\
\hline May $12-18$ & & & & & & & & \\
\hline Blowdown & 0.20 & $<0.01<$ & 0.05 & $<0.1$ & $<0.005$ & $<0.05$ & - & $<0.01<0.01$ \\
\hline Blowdown Demin< & 0.01 & $<0.01$ & - & $<0.1$ & - & - & -- & $-<0.01$ \\
\hline Condensate & 0.15 & $<0.01$ & $<0.05$ & $<0.1$ & $<0.005$ & - & $-\infty$ & $<0.01<0.01$ \\
\hline Feedwater & 0.10 & $<0.01$ & $<0.05$ & $<0.1$ & $<0.005$ & $<0.05$ & 0.05 & $<0.01<0.01$ \\
\hline Makeup Demin & -- & $<0.01$ & - & - & - & $<0.05$ & - & $<0.01<0.01$ \\
\hline Steam & 0.10 & $<0.01$ & - & $<0.1$ & - & $<0.05$ & - & $<0.01<0.01$ \\
\hline
\end{tabular}


TABLE IX. $\mathrm{pH}$ of Steam-Feedwater System for Run 40

\begin{tabular}{|c|c|c|c|c|c|c|c|}
\hline Date & & Condensate & Feedwater & Blowdown & $\begin{array}{l}\text { Blowdown } \\
\text { Demin }\end{array}$ & $\begin{array}{l}\text { No. } 2 \\
\text { Heater }\end{array}$ & Steam \\
\hline \multirow{28}{*}{$\begin{array}{r}\text { February } \\
(1970)\end{array}$} & 1 & 9.3 & 9.2 & -- & -- & -- & -- \\
\hline & 2 & 8.9 & 9.2 & -- & -- & -- & -- \\
\hline & 3 & 9.1 & 9.0 & 9.1 & 9.1 & 9.3 & 8.1 \\
\hline & 4 & 9.2 & 9.1 & -- & - & -- & -- \\
\hline & 5 & 9.1 & -- & - & 8.2 & 9.2 & -- \\
\hline & 6 & 8.9 & 8.8 & -- & 8.6 & 9.3 & -- \\
\hline & 7 & 9.3 & $9 . ?$ & -- & -- & -- & -- \\
\hline & 8 & 9.1 & 9.2 & -- & - & - & -- \\
\hline & 9 & 9.0 & 8.9 & 9.0 & 8.3 & 9.2 & 9.2 \\
\hline & 10 & 9.2 & 9.4 & -- & $=$ & -- & - \\
\hline & 11 & 9.2 & $9.1^{\circ}$ & 9.3 & 8.1 & 9.5 & 9.4 \\
\hline & 12 & 9.5 & 9.5 & 9.2 & 8.3 & 9.5 & 9.5 \\
\hline & .13 & 9.0 & 8.9 & 9.0 & 8.2 & 9.2 & 9.2 \\
\hline & 14 & - & - & - & -- & - & $\ldots$ \\
\hline & 15 & 9.2 & 9.1 & -- & -- & -- & -- \\
\hline & 16 & 9.0 & 9.0 & 9.5 & 8.5 & 9.6 & 9.6 \\
\hline & 17 & 9.4 & 9.4 & 9.1 & 8.7 & 9.5 & 9.4 \\
\hline & 18 & 9.4 & 9.4 & 9.4 & 8.4 & 9.3 & 9.3 \\
\hline & 19 & 9.0 & 8.9 & 8.9 & 8.3 & 9.0 & 8.8 \\
\hline & 20 & 9.2 & 9.4 & 9.2 & 8.3 & 9.3 & 9.0 \\
\hline & 21 & 9.1 & 9.4 & -- & -- & -- & - \\
\hline & 22 & 9.1 & 9.2 & -- & -- & -- & -- \\
\hline & 23 & 9.1 & 9.2 & 0.9 & 8.3 & 9.4 & 9.4 \\
\hline & 24 & 9.1 & 9.1 & 9.4 & 8.5 & 9.4 & 9.4 \\
\hline & 25 & $y .1$ & 9.1 & 0.3 & 0.1 & $9: 3$ & १.? \\
\hline & 26 & 9.2 & 9.2 & 9.2 & 8.2 & 9.3 & 9.3 \\
\hline & 27 & 9.1 & 9.3 & 9.3 & $8 . \overline{7}$ & 9.5 & 9.4 \\
\hline & 28 & 9.3 & 9.2 & -- & -- & - &,-- \\
\hline March & 1 & 9.3 & 9.2 & -- & -- & -- & -- \\
\hline
\end{tabular}


TABLE X. pH of Steam-Feedwater System for Run 44

\begin{tabular}{|c|c|c|c|c|c|c|c|}
\hline & & Condensate & Feedwater & Blowdown & $\begin{array}{l}\text { Blowdown } \\
\text { Demin }\end{array}$ & Heater & Steam \\
\hline June & 24 & 9.1 & - & - & -- & -- & - \\
\hline \multirow{6}{*}{ (1970) } & 25 & 8.7 & -- & -- & -- & -- & -- \\
\hline & 26 & 8.8 & -- & -- & - & -- & - \\
\hline & 27 & 8.8 & 8.8 & -- & -- & -- & - \\
\hline & 28 & 8.9 & 8.8 & -- & -- & -- & -- \\
\hline & 29 & 8.9 & 8.8 . & 9.1 & 7.6 & 9.3 & 9.2 \\
\hline & 30 & 8.8 & 9.0 & 8.7 & 7.4 & 8.9 & 8.9 \\
\hline \multirow[t]{31}{*}{ :July } & 1 & 9.0 & 9.0 & 9.0 & 7.8 & 9.2 & 9.1 \\
\hline & 2 & 9.2 & 9.2 & 9.1 & 7.6 & 9.2 & 9.0 \\
\hline & 3 & 9.2 & 9.2 & -- & -- & -- & -- \\
\hline & 4 & 8.9 & 8.9 & -- & - & -- & - \\
\hline & 5 & 8.9 & 9.0 & - & - & -- & -- \\
\hline & 6 & 9.2 . & 9.0 & 8.9 & 7.7 & 9.2 & 9.4 \\
\hline & 7 & 9.1 & 9.1 & 8.9 & 7.7 & 9.2 & 9.4 \\
\hline & 8 & 9.1 & 9.1 & 9.0 & 8.0 & 9.2 & 9.2 \\
\hline & 9 & 8.9 & 9.0 & 8.7 & 7.3 & 8.9 & 8.9 \\
\hline & 10 & 9.1 & 9.1 & 9.1 & 8.4 & 9.3 & 9.3 \\
\hline & 11 & 9.0 & 8.7 & -- & -- & - & - \\
\hline & 12 & 9.1 & 9.2 & - & -- & -- & -- \\
\hline & 13 & 9.0 & 9.1 & $9: 2$ & 7.8 & 9.3 & 9.3 \\
\hline & 14 & 9.1 & 8.9 & 9.1 & 7.4 & 9.3 & 9.3 \\
\hline & 15 & 9.0 & -- & -- & -- & -- & - \\
\hline & 16 & -- & -- & -- & -- & -- & -- \\
\hline & 17 & -- & -- & -- & - & -- & -- \\
\hline & 18 & -- & -- & -- & - & -- & - \\
\hline & 19 & -- & -- & -- & -- & -- & -- \\
\hline & 20 & -- & -- & -- & - & -- & -- \\
\hline & 21 & $\therefore$ & - & -- & $\therefore-$ & $=$ & - \\
\hline & 22 & -- & -- & -- & -- & -- & - \\
\hline & 23 & -- & -- & -- & -- & -- & -- \\
\hline & 24 & -- & -- & -- & - & - & -- \\
\hline & 25 & -- & - & - & - & - & -- \\
\hline & 26 & 9.1 & 9.1 & - & - & - & - \\
\hline & 27 & 9.0 & 9.2 & 9.1 & 8.0 & 9.2 & 9.3 \\
\hline & 28 & 9.0 & 9.2 & 9.2 & 8.1 & 9.3 & 9.3 \\
\hline & 29 & 9.1 & 9.1 & 8.9 & 7.9 & 9.2 & 9.1 \\
\hline & 30 & 9.1 & 9.2 & 9.2 & 8.2 & 9.3 & 9.2 \\
\hline & 31 & 9.0 & 9.1 & 9.1 & 8.1 & 9.2 & 9.1 \\
\hline \multirow[t]{4}{*}{ August } & 1. & 9.1 & 9.1 & - & - & - & - \\
\hline & 2 & 9.1 & 9.1 & $\rightarrow$ & - & - & - \\
\hline & 3 & 9.1 & 9.1 & 9.1 & 7.9 & 9.3 & 9.2 \\
\hline & 4 & - & - & - & $\rightarrow$ & $\rightarrow$ & - \\
\hline
\end{tabular}


REFERENCE

1. H. W. Buschman, The EBR-II Steam Plant: Operating Experience and Performance Evaluation, ANL/EBR-087 (September 1974) 